\title{
Gendered Pathways to Power
}

\author{
Identifying the Role of County Party Chairs \\ in the Candidate Recruitment Process \\ of Pennsylvania's Local Elective Offices
}

DANA BROWN

Chatham University

The Commonwealth of Pennsylvania has historically fared poorly in terms of the proportion of women serving in its governing bodies. After a historic year of women in politics in 2018, Pennsylvania increased its proportion of women serving in the state legislature from $19 \%$ to $26 \%$, which is still far from parity. Why are women so underrepresented? Political scientists have tested various variables: women's lack of political ambition, negative gatekeeping by political parties, and gender stereotypes negatively impacting female candidates, just to name a few. This paper focuses on the role that county party chairs and vicechairs play in recruiting female candidates to run for political office in Pennsylvania. In this article I ask: what do the recruitment efforts look like on the ground and how are the recruitment efforts gendered? In terms of recruitment efforts, I expect the stronger county party to have its leaders pull from informal networks that are extensions of the party leaders themselves. On the other hand, I expect weak county parties to cast a wide net for candidate recruitment and allow candidates to self-identify, which I call the "volunteer" model. I use interview data of county party chairs in order to understand the structure of candidate recruitment in Pennsylvania and the impact it may have on candidate selection.

COMMONWEALTH, Volume 21, Issue 1 (2021). (C) 2021 The Pennsylvania Political Science Association. ISSN 2469-7672 (online). http://dx.doi.org/10.15367/com.v21i1.287. All rights reserved. 
cholars have used a myriad of methods and theories to understand why women remain underrepresented in elective office. ${ }^{1}$ However, the extant literature specifically on the puzzle of women and politics in Pennsylvania is quite scarce. Scholars Deber (1982) and Hansen (1994) have focused their efforts on the lack of gender diversity amongst the state's federal delegation.

Deber (1982) asks why so many of Pennsylvania's congressional candidates are white, middle-aged, and male. Her analysis focuses on the role of the individual and how women hold themselves back from running for office based on societal norms. She fails to consider the role that institutions such as political parties play as gatekeepers to electoral politics. A decade later Hansen (1994) primarily investigated why former Democratic U.S. Senate candidate Lynn Yeakel lost her bid in 1992 to Senator Arlen Specter. Her work revealed four main reasons for the paucity of women in Pennsylvania politics: (1) a traditional political culture, (2) the strong party system, (3) a male-dominated party structure, and (4) the professionalized legislature. Each worked to keep women's representation low.

This article aims to better understand the underrepresentation of women in Pennsylvania politics as a function of the state's traditional political culture, its strong party system, and the candidate recruitment practices of its political parties. Specifically, what role do county parties play in recruiting female candidates to run for political office in Pennsylvania? Additionally, there is tension among the gender and party politics literature as to whether the party structure is advantageous to female candidates (Crowder-Meyer 2010) or an obstacle (Niven 2006; Sanbonmatsu 2006). Lastly, this article studies candidate recruitment practices at the local level, which is important given that most individuals who hold elective office do so at the local level (Trounstine 2008).

Relying on county party leader interviews, this article offers a narrative of the following three elements of the candidate recruitment process in Pennsylvania: what the candidate process looks like across county parties, the impact of these practices on women's representation, and the role that elite attitudes about women and politics play.

\section{Candidate Recruitment}

In an attempt to learn about what role political elites and their organizations play in perpetuating the underrepresentation of women in government, Niven (1998) surveyed county party chairs and locally elected women from four states $^{2}$ to determine if there was a male selection bias in the chairs' recruitment efforts. Niven found that there was evidence of an in-group preference 
where the predominantly male party chairs favored masculine traits from occupations to personalities. Of the female officeholders surveyed, $64 \%$ said that party leaders actively discouraged their candidacy. Burrell coined the term "selectorate" to refer to party members involved at some stage in shortlisting candidates $(1993,291)$, but from Niven's research we learn that the selectorate can also exist on the local level, which impacts the pipeline of female candidates.

Sanbonmatsu (2006) investigated the role that political parties play in the candidate recruitment process for state legislatures across six states ${ }^{3}$ by interviewing and surveying party leaders. The party leaders' responses were as diverse as the states studied, but there were some patterns that emerged. Like Niven, Sanbonmatsu found that the "selectorate" recruited candidates from the recruiters' own personal network. Sanbonmatsu also confirmed a correlation between states with strong parties and fewer female candidates. When parties were strong, women tended to be ignored while men were actively recruited and endorsed.

Crowder-Meyer (2010) found that strong, active, and structured parties ran more female candidates than weak parties. Crowder-Meyer found this pattern to be even more pronounced in the Democratic Party than in the Republican Party when women led the local parties. Parties that worked with non-party groups such as community groups, volunteer organizations, and outside interest groups ran more female candidates, as women are more likely to participate in non-party groups than in political party organizations. Less traditional means of recruitment are decidedly more effective at recruiting women:

Party leaders who look for candidates using traditional party member and officeholder networks will be more likely to find male candidates, while those who look beyond the party in sub-county offices and social networks of party members will be more likely to find female candidates. (Crowder-Meyer 2013, 409)

I investigate how and when county party leaders rely on informal networks to identify potential candidates in Pennsylvania. I consider how county party leaders explain the paucity of women in Pennsylvania politics and the gendered implications for our representational bodies of government.

\section{All Politics Is Local}

Simply because women are holding office at local governments at slightly higher rates than the federal level, this in no way means that women are 
present in local governments at a desired level (Dolan, Deckman, and Swers 2007). Thus, studying candidate recruitment at the local level is still a largely underdeveloped and highly relevant area to explore in order to better understand the underrepresentation of women in Pennsylvania politics. Pennsylvania has many of the variables that women and politics scholars use to predict lower representation of women, such as a professional legislature, traditional political party structure, and support for traditional gender roles ${ }^{4}$ (NCSL 2017). In light of Crowder-Meyer's (2010) arguments that strong parties may potentially benefit women's candidacies, Pennsylvania boasting a historically "strong" party system represents a good test case of the role that parties may play in the recruitment process.

\section{Candidate Recruitment Typology}

I anticipate that Pennsylvania's county political parties will rely mostly on informal recruitment efforts to identify candidates. Informal candidate recruitment is defined as political party officials identifying and encouraging potential candidates to run who are already "favored" by party elites, thereby perpetuating the political culture of exclusivity. Informal recruitment tends to draw from men and women who are close with party officials, if they are not already party activists themselves. The unintended gendered consequence of this informal recruitment effort is that party leaders may be choosing from male-dominated networks (Crowder-Meyer 2013; Niven 2006; Sanbonmatsu 2006).

Drawing from previous work that has found Pennsylvania's political culture to be traditional and conservative, I can anticipate that this culture will have an impact on candidate recruitment practices (Brown 2015; Deber 1982; Hansen 1994). Therefore, I argue that party elites will discuss the paucity of women in politics through a discriminatory lens of benevolent sexism. Glick and Fiske (2001) define benevolent discrimination as being in the "woman's best interest," which allows it to be more widely accepted and pervasive.

\section{Political Party Strength and Recruitment Efforts}

County party strength derives a portion of its power from voter registration. Therefore, in each of the 67 county parties in Pennsylvania, one will find a party that is stronger than the other-a majority party and a minority party. I expect the stronger county party to engage in informal recruitment efforts. However, due to the overall political culture of the state that was deemed strong (Hansen 1994; Mayhew 1986), the minority county party may also 
engage in informal recruitment activities as a default due to lack of resources. While the stronger party may be informally recruiting from an exclusive tier of individuals in the community; the weaker party may use its informal network to draw from as well, with differing electoral success. I also anticipate that the minority party may also engage in "volunteer" recruitment and allow candidates to self-identify and come forward to the party given the lack of institutional resources at their disposal. However, if desperate to field a candidate for an open position, the weaker party may engage in "formal" recruitment efforts. Unfortunately, there are gendered outcomes in all of these types of recruitment efforts.

\section{Methods}

Thirty chairs and vice-chairs, representing 23 counties, were interviewed out of the universe of 281 chairs and vice-chairs across Pennsylvania. The interviews were conducted via telephone between September 2012 and March 2013. Of the 30 interviews, 18 were Democrats and 12 were Republicans, 14 women and 16 men. The interviews lasted, on average, half an hour and were recorded. The interview topics included: the party's role in recruitment; the activities of the county party; party assistance with candidates; observations on the role of gender in seeking election; what groups, if any, the party works with to identify candidates; and observations as to why there are so few women in Pennsylvania politics. Interviews were chosen as a form of inquiry in order to understand party elites' complex attitudes toward recruitment and more specifically what role gender plays, if any, in their local politics.

I rely on an interpretative approach (Soss 2005). The interpretative approach is one that allows the researcher to remain analytical and not simply code and accept a respondent's description on face value. Rather, researchers must make sense of statements contextually to give it meaning.

\section{Analysis}

From the interviews, patterns emerged: 15 interviewees identified using informal recruitment through personal/organizational networks; 0 interviewees identified solely relying on formal recruitment through paid advertisements; 4 interviewees described a lack of recruitment by using the volunteer approach; 3 respondents spoke of using a mix of informal and formal models; and 7 spoke of recruiting by using both informal and volunteer efforts. This section will highlight examples of these patterns of recruitment discussed by Pennsylvania county party leaders. 


\section{Informal Recruitment Model}

The most prevalent of the various types of recruitment was informal, which is typified by 15 interviewees. The interviewees explained the informal process of party leaders talking to people they know about possible openings in upcoming elections. Evidence of informal recruitment was plentiful and discussed by county party leaders in all pockets of the Commonwealth. Describing his candidate recruitment method, Roger Lund, the Democratic Chair of Adams County, provides a thorough explanation of his county's informal recruitment method and why formal advertisements are less desirable:

It's mostly through other party mechanisms because you can advertise something in the paper and you get some wing-nut that wants to be on your party's ticket, and so we try to not do that. It's more of a case of networking through people we know. We will put the word out through our county committee and say, 'Do you have people within your church, do you have people within civic organizations that belong to the fireman's fire halls or whatever that might have an interest in running for office?' And a lot of times we'll also look at people who are sitting on borough councils, mayors throughout the county to see if they have any interest in running for offices that are higher level. So, we cast kind of a wide net, we don't do any advertising per se, it is word of mouth. (Lund 2012)

In this introductory explanation of how recruitment is done at the county level, Mr. Lund identifies the possible gendered consequence of putting "the word out." When instructing other committee members to recruit candidates, he begins by stating that they begin with an informal process by "networking through people we know" (Lund 2012). He goes on to mention organizations that are heavily male dominated: fire halls, borough councils, and mayor's offices. The "people we know" he mentions will most likely look much like the people doing the recruiting. Mr. Lund is describing a potentially gendered process with gendered consequences, even though he believes he casts "a wide net." In sum, the process in Adams County, located in south-central Pennsylvania, is quite typical of county parties as their process begins internally and then looks outwardly at those related to the party network. This example is one that echoes the work of Sanbonmatsu (2006) and Crowder-Meyer (2013) as it has all of the hallmarks of an informal recruitment process, yet the process is being led by the minority party of the county (the Democratic Party). ${ }^{5}$ 
Similarly, the Republican Chair of Blair County, Mr. Stickel, articulates the informal process that often begins internally to identify and recruit candidates before moving on to the outside community:

I, as chairman or sometimes somebody who is on that committee will sort of identify somebody who has risen to the top. We get to know them through the campaign so somebody who's out there now working for a presidential candidate, or one of our other candidates, who really steps up and takes a leadership role-that's really the first chance we get to know some people. Then sometimes we'll discuss with them, "Have you ever considered running for office? Here are some needs." The second thing that we do, that we're starting to do more and more, is work with the Chamber of Commerce, to work within other organizations to see people who are in leadership positions there who've done a good job and support our principles and our platform. (Stickel 2012)

Again, it is important to note that county party leaders may not be intentionally recruiting from one gender more than the other through their informal recruitment process. However, many county parties continue to rely on the same internal and informal structures of the party that helped create the gender gap of elected officials in Pennsylvania politics. Further, the organization that the chair identifies to help with recruitment, the Chamber of Commerce, is heavily male dominated as it is an entity that promotes business interests to governing bodies. What is most interesting about Mr. Stickel's interview is that while he believes he has an open-door policy on candidates, many of the tactics on how and when to recruit candidates can lead to favoring the male party regulars.

\section{Mixed Model: Informal and Volunteer}

Jeff Smith, Republican Chair of Butler County, provides an example of informal networks and a volunteer model being deployed to recruit candidates by his Republican Party:

We would talk to the committee people, and this is primarily at the municipal level, maybe talk to other municipal officials in that area to try to identify somebody. We've also-we're trying to get the word out through the committee people through the periodic occasional speaking opportunities that if people are interested in running to be sure and contact me. (Smith 2012) 
In Mr. Smith's example, Republican committeemen and women are asked to dispatch around the county and speak to groups. In this instance they are relying on the party's network to meet with organizations and recruit from the groups they speak to. As he continued with his statement, he made it clear that people were able and encouraged to self-identify and then be vetted by the party apparatus.

One area of agreement among party leaders was incumbency protection. While not all county party leaders mentioned incumbency, when leaders did speak of it, they spoke of deferring to incumbents on their decision to run again. The process of most county party leaders was to allow incumbents first right of refusal to run, and if the incumbents declined to run, then and only then would the county parties begin to recruit for those seats.

\section{Mixed Model: Formal and Informal Recruitment}

While no county party leader identified relying solely on formal recruitment efforts exemplified by paid advertisements, three county party leaders explained that they use formal and informal methods in order to recruit candidates. One of those county party leaders was Allegheny County Democratic Committee Chair Dr. Nancy Mills. At the time of the interview, a special election was under way and Dr. Mills ${ }^{6}$ used that election as an example in many of her comments on recruitment. When asked if the recruitment process for the election was formal or informal she responded in the following way:

I have been open to anybody who would call to inquire. Now, this would just be the informal by word of mouth - the insiders know that the seat's coming up, I let the public know too because I've been interviewed by the Tribune Review and the Post-Gazette on this subject. So, now to get into a formal invitation to apply ... we send out a letter to all of the chairs of the different municipalities within the 42nd district to advise them that we are going to be nominating a candidate for that seat. We also advertise it on our website and we also send out a press release to all the media to advise the general public what seat it is, when it will be available, and what the filing dates are to be a candidate for the seat. So, we have informal and formal. (Mills 2012)

What is typical in her response is her reliance on informal "word of mouth" and the expectation that "insiders know that the seat's coming up." Because it is a special election in the second-most populous county in the state, there is increased press coverage that many other elections would not garner. So, Dr. Mills, the party chair, uses the press to share the information with the 
public as well as on the Democratic Party's website. Due to the fact that this is a special election, no primary was to take place-in order to get on the ballot, one needed to be nominated by the Democratic Party. Hence, the role of "insiders" and party officials played very prominently. In Allegheny County the Democratic Party relies on a mix of both formal and informal processes to ferret out candidates. More generally, Dr. Mills explains that recruitment is ongoing:

We do not have a specific committee just to recruit candidates because it's too specific ... that's why we have chairs in all of our municipalities. So, if they're going to look for a candidate, for instance, for the school board in Moon Township, then the local chair is looking all the time... every meeting they go to within the community ... you sort of get into the feel of it, you're always looking for someone to run someday and so people ... say you were in Moon Township and they saw you and thought, "Boy, Dana would be a great candidate," they might invite you to be a member of the local committee so that you can learn the political process from the real grassroots and understand what the procedure is to become a candidate. (Mills 2012)

Unfortunately, the informal recruitment process may also have a gendered outcome, as it relies on individuals' own subjective ideas about what a leader looks and sounds like. We know from gender stereotype research that individuals can react to leadership styles in a very gendered way (Bauer 2015, 2018; Ditonto 2017; Huddy and Terkildsen 1993). However, Mills makes it very clear that her party is actively recruiting and targeting women to run for public office. Dr. Mills is well aware of the interviewer's role and work at the Pennsylvania Center for Women and Politics at Chatham University and has participated in the center's Ready to Run ${ }^{\text {tw }}$ Campaign Training for Women as a speaker on party politics. This is important to acknowledge because the interviewee kept actively stating the role of the party in recruiting women, yet at the time of the interview there was only one woman from the county serving in the state legislature. Only recently, in the 2018 election, did Allegheny County elect six women to the Pennsylvania State House of Representatives and two to the state senate. ${ }^{7}$ It is possible that social desirability affected her responses given how few women were actually serving at that time.

I was able to determine that the Allegheny County Democratic Committee (ACDC) uses a mix of informal personal networks and formal news and website outlets as the primary mechanisms for recruitment. The volunteer model at the ACDC was discouraged, as Dr. Mills stated, "It doesn't work 
by just coming in from the outside and say I think I'll run. Pay your dues, maybe that's the easiest way to describe it. You hear it all the time. I hate that expression, but I think that it probably does apply" (Mills 2012). One could also interpret that as the majority party in the county with $56 \%$ of the voters in the county supporting Obama in 2012 (Politico 2014), her discussion of volunteerism is a signal of the negative gatekeeping that occurs when a volunteer emerges. Similar to Mr. Stickel, the Republican Chair of Blair County, Dr. Mills first looks internally to insiders and her networks to recruit, but differs in that she favors "paying one's dues" to the party before getting the support to run. Paying one's dues and being told to "wait your turn" are gendered responses with gendered consequences as it is men who have tended to be with the party for longer periods of time (Sanbonmatsu 2006).

Other organizations use a mix of recruitment methods as well. As Marilyn Levin, Chair of the Democratic Party of Dauphin County stated:

Currently, we have a candidate recruitment committee. ... They have been given a budget so that they can advertise in local newspapers or the major newspaper if they choose.... In the past ... me and the candidate's chairman did most of the work finding people. Well, I don't think that's a successful way to build an organization, so I've set this new way up and we've expanded the candidate's committee. I've given them free reign to go ahead and recruit candidates and interview candidates. (Levin 2012)

Ms. Levin articulated a process wherein a committee of individuals seeks potential candidates and reviews their resumes, and the two ways to reach those potential candidates, through paid advertisements and networks of the recruitment committee.

\section{Volunteer Recruitment Model}

The volunteer model was articulated by four county party leaders. This model is one that waits for potential candidates to approach the political party committee. Bill Benner, Republican Chair of Perry County, offers a primary example of relying on "volunteerism" to recruit candidates for public office:

While it's not a formal process, it's when there is a vacancy, often someone has pre-positioned themselves to run for that vacancy, or perhaps two or three people have pre-positioned themselves to run for that vacancy. So, the committee themselves really is not engaged 
actively in trying to go out and find folks, usually folks come out to us. (Benner 2012)

Mr. Benner makes clear that candidates are self-determined as the committee members respond only when candidates present themselves. Even more to the point is a male Democratic County Party Chair who did not want to be identified. When asked about his county party's recruitment process he responded: "Well, I don't think there's anything terribly serious about it; there are people who raise their hands and volunteer, so to speak, and then come to the county committee in search of support." From this I gather that the committee is quite passive and does not seek candidates, but rather candidates self-identify. Thus, the process can be inherently gendered favoring entrepreneurs who historically have been male (Lawless and Fox 2005, 2010; Sanbonmatsu, Carroll, and Walsh 2009).

Another example of the volunteer recruitment approach can be found in the Republican Party of Blair County. Mr. Donald Belsey, Party ViceChair states, "as far as the process is concerned, no, it doesn't exist. The most important thing that we come across is the fact, people themselves, if they opt to become candidates then they approach us" (Belsey 2012). Again, I would argue that this type of recruitment has a very gendered consequence. The lack of targeted recruitment and failure to ask women to run translates into fewer female candidates. Both Lawless and Fox (2010) as well as Crowder-Meyer (2013) indicate that if and when parties do intentionally recruit women to run for public office, women are more likely to agree to be candidates. Yet, this is not happening regularly across the county parties in Pennsylvania.

Parties may go on to invoke any or all recruitment practices depending on the electoral climate at the time. The Chair of the Blair County Republican Party, Mr. Stickel discusses the intersection of recruitment practices, incumbency protection, and gatekeeping:

Sometimes people will come to us and say, "Hey, I'd like to run." Let me go on to say that nobody needs my permission to run and that might be unique. I know that there are some county committees, not necessarily Democrats or Republicans are unique to that, but there are county committees or county chairmen that feel like you need to get their blessing to run. That's not why I'm here or why our committee's here. If you're committed to run then we'll help you. We only recruit candidates where there is no candidate, or where there's essentially a very weak candidate. As a committee we don't go out and recruit 
candidates to run against incumbents, not that we absolutely support incumbents, but we're not going to find somebody to run against them. (Stickel 2012)

Mr. Stickel argues that if a newcomer from outside the party structure wants to run and there is no incumbent, the party will not prevent him or her from running, which is not the case in all county parties. Certainly, if you are an outsider coming to the party, they too will encourage you and you will not need to wait in order to run for public office.

Based on previous political science work, all of the recruitment models identified have a potential gendered consequence that favors male candidates. Given all of the work done on the gendered political ambition gap (Lawless and Fox 2010) and knowing that men are more likely to run for office simply to "fulfill a long-term goal" (Sanbonmatsu, Carroll, and Walsh 2009), the volunteer model leads us down a path where mostly males will self-identify as candidates. It is quite possible that many party leaders, including Mr. Benner, view the "volunteer" model as being gender neutral, but the political science literature points to a very gendered consequence that can favor male candidates from this recruitment practice.

\section{Gatekeeping}

Overall, there were only a few cases of gatekeeping articulated by the party leaders. Previous work on Pennsylvania has indicated that it is a strong party state, meaning that one would expect to have strong gatekeeping measures, especially that of a formidable endorsement process. Therefore, political newcomers like women would have a difficult time breaking into this old system that essentially promotes from within. Moreover, the Pennsylvania party system has been previously described as the primary gatekeeper as to whether or not a candidate could even run, let alone seek the endorsement.

A male Republican County Chair explains the role of many county parties regarding gatekeeping, recruitment, and endorsement:

Once upon a time before I was chairman [there] had [been] a very heavy machine, [county] party machine, and you see it a lot in the counties and suburban southeastern Pennsylvania. Montgomery County, Delaware County, Chester, Bucks, these are known for having very strong machines such that, really the only way you get to run for office and have a viable chance of winning is if you have the blessing of that machine. ${ }^{8}$ 
A handful of examples offered by county party leaders in the interviews revealed that they mainly deterred candidates from running if they felt that the potential candidate lacked name recognition or had some type of criminal background. So, for some potential candidates, party leaders would redirect them and encourage them to involve themselves in the community more before running for office. If a potential candidate had a criminal background, they deterred the candidate from running to protect the party and the individual from humiliation. Other leaders acted as gatekeepers by redirecting potential candidates to offices more appropriate to match the individual's credentials. A Republican male county party chair stated that he deterred candidates:

Not for any fundamental reason, meaning, not because I want to clear the field for anyone; but I have suggested to people that while they're free to run, they may not have what's really required to run at the level they're choosing. And I would suggest that they try something more appropriate to them. ${ }^{9}$

The party leader's words are very subjective here, which can lead to male selection bias (Niven 2006).

We know from experimental work (Bauer 2015, 2018; Ditonto 2017; Huddy and Terkildsen 1993) that gender stereotypes often inform how an individual evaluates candidates both on traits as well as on issue competencies. Therefore, it is always a bit concerning when any party official has chosen to be the arbiter of experience in order to run. Delving deeper into the process of gatekeeping, State Senator Wayne Fontana who served briefly as Vice-Chair of the Allegheny County Democratic Committee:

So, in order to gain name recognition, in order to run a campaign to beat an incumbent possibly, it may take a lot of money, and it may not be able to be attained. So, you may have to wait. You may have to say, "Well don't run this time, run next time," or you need to begin to work the political system and get your name out there on your own, a year or two ahead by just going out and meeting people and those kinds of things before you actually run for office. And a lot of times it's a timing thing, it's about the timing of the actual race. (Fontana 2012)

Similar to Senator Fontana, Christopher Decker of the Republican Party of Pike County explained that he might engage in negative gatekeeping through an "off-the-record conversation with a candidate and telling them that it 
might not be in the best interest of the party just because it would cause a split, or they would lose . . . but it would have to take some very serious circumstances for that to happen" (Decker 2012).

Other examples of gatekeeping were explicitly based on gender stereotypes. Ruth Ann Shaffer, Democratic Vice-Chair of York County, provided examples of when she and/or another party leader had to deter a candidate from running. Ms. Shaffer quickly offered an example involving a woman who was turned away to rethink running for school board until her children were older. She stated:

It was a woman and she didn't have, again it was for school board, and we told her she'd be perfectly fine to run for the school board, but she needed to be honest and realistic about how much time she would be able to give to the school board because she had-I think it was five children and they were all under the age of 16. Education wise she was great, but since most of us had served on a school board, we knew how much time was involved and we told her to think about it and come back the following week. And she came back and thanked us for listening to her and she decided not to until her children were older and we said that would be great. She really would have been well qualified, but we didn't know that she would have the time for that. We're pretty frank. (Shaffer 2012)

Based on Ms. Shaffer's example, the county party leaders did not immediately turn the woman away from running, but they did plant the seed of doubt in her head and had her think about it. Returning to the political ambition and confidence literature, it is not surprising that the woman erred on the side of caution about being able to manage the elective and domestic duties. Additionally, a female county leader who has some authority on the matter deterred the potential candidate, which is not surprising given that both women and men are susceptible to perpetuating gender stereotypes. Interestingly, not one county party leader gave an example of suggesting to a male candidate that he reconsider running because he had young children at home.

While there are cases of negative gatekeeping across Pennsylvania, there were some county party leaders who indicated that they were actively changing their by-laws to ensure that they were no longer gatekeepers. Rather, they preferred to have the primary process take place and give voters the power to act in that capacity. One can chart this transition with fewer county parties engaging in an endorsement process than they once had and certainly with fewer leaders actively deterring candidates. However, when party leaders do 
choose to deter folks, it could have a more negative impact on women's candidacies than men's-whether it is through subjective comments about "waiting your turn," making sure the office sought and the candidate's qualities are a match, or the sexist comments that women should wait until their childrearing responsibilities dissipate.

\section{Pennsylvania's Political and Social Culture}

"It's traditional." Throughout many interviews there was a statement, example, or insinuation that Pennsylvania's political, social, and cultural orientation was "traditional" in some fashion. However, party leaders were also quick to explain that both the state's culture and party organizations were very slowly transitioning to a less conservative atmosphere. I did not specifically ask what the culture of the state was, but two questions in particular seemed to really draw it out: (1) "Have you noticed any patterns that women and men take to get elected to county or state office in terms of past experience? Recruitment? Officeholding?" (2) "Some people say that men make better candidates for some elective offices than women. Or, that women make better candidates for some offices than men. Based on your experience as a county party leader, why do you think people believe this?" Through these questions, respondents established themselves in one of three camps: first, they believed that many citizens of Pennsylvania, but not themselves, still hold onto strong gender stereotypes; second, they believed in traditional gender stereotypes, without explicitly stating it; or third, gender stereotypes may have mattered, but Pennsylvania was slowly changing like the rest of the United States. In total, many leaders provided very stereotypic examples of offices that were better suited for men and women. By doing so, the county party leaders tangentially spoke about the culture of the political parties and their communities.

William Miller, Democratic Chair of Clarion County, was reluctant and not proud to say it, but in his county, women rarely run for elective office. According to the Pennsylvania Center for Women and Politics at Chatham University, only 21\% of Clarion County's elected officials were women in 2012 when the interview took place. Why? He states because it is "so traditional here" (Miller 2012). When asked to further explain that statement, Mr. Miller clarified:

Well, I mean, you look back in history here, I doubt if there's ever been a woman even run for sheriff, let alone serve, and the same with coroner. I've been here 30-some years and can't ever remember a woman running for coroner. Mostly the [female] candidates that have been 
successful here have been in the prothonotary's office, in the treasurer's office. We've only ever had, that I can remember, one auditor that a woman had accepted that position. So, yeah that's pretty much the way it has been. Like I said the coroner and sheriff are the two primary examples. (Miller 2012)

He went on to explain that many women in his county are active in local politics and are engaged, but they are not running for office; rather, they are support staff to those positions. His explanation as to why women are not engaged on that electoral level is telling of the culture both socially and politically:

And I think it might be the type of area we are. We have a very rural population here and it's, I don't want to say male dominated, but I guess there is a little bit of that and so I think that's possibly it. The society up here is rural and, I don't know whether it has to do with religion or just sociology, or whatever. (Miller 2012)

Mr. Miller and other county party leaders spoke of the cultural divide: rural versus urban areas. He also mentioned that the gender disparity in office might be a symptom of the lack of diversity in women's professions in his rural area. He pointed out that if there are not many female lawyers in his county that will impact who runs for district attorney or judges, for example. Perhaps women in his rural area do not feel that they can or should pursue the law as a profession because it goes beyond their construct of what a woman's role is in their society. After all, there are plenty of women in the labor force in Clarion County. According to Palmer and Simon (2012) these demographic variables are indicators of women's presence in elected bodies. Thus, the culture, the demographics, and party system collide in every county to affect women's pathway and likelihood of holding elective office.

In response to the question if there were any patterns in men and women getting elected to office, Megan Carpenter, Republican Chair of Beaver County, said:

I would have to say, sadly, that it is very rare for a woman to get elected here. We have two representatives on our side and a senator on our side who are all male. The other ones are all male that are on the Democrat side. . . . It seems like it's a lot harder for women to get elected quite honestly, and I think that's regardless of your party. We do have a few row offices in the courthouse that are female that are Democrats. (Carpenter 2013) 
Ms. Carpenter's comment is one that was echoed by many county party leaders on both sides of the aisle. Her quote makes sense, as there are so few women who hold or have held elective office in Pennsylvania. However, according to some political leaders, like Ms. Carpenter, there seems to be some traction for female candidates running for county row offices. Row offices are the countywide elective offices like controller, treasurer, prothonotary, coroner, register of wills, and so on. Many of the offices are more administrative in nature. According to the Pennsylvania Center for Women and Politics at Chatham University, women hold approximately $37 \%$ of the countywide positions. Marcia Williams, Vice-Chair of the Adams County Democratic Committee, buoys the point:

The one area where there are female candidates successful is in the county row offices. The clerk of courts, the prothonotary, the county treasurer; the men don't seem to run for those offices. I guess because they're considered "office work." ... The men are not running for those offices except on rare occasions ... almost always female candidates of both political parties ... so, we do have women in office in the county, but they are holding the administrative positions rather than the commissioner positions, or the state legislature positions. (Williams 2012)

Ms. Williams and Ms. Carpenter both notice the same pattern in their counties of women getting elected to the more administrative offices even though they are on opposite sides of the political aisle and are from different geographical areas. This is a pattern that, unfortunately, neatly maps gender stereotypes-returning to the notion that Pennsylvania's culture is traditional, which informs the recruitment efforts of both parties. It seems that women can and do run for office and assumingly are encouraged to do so for administrative row offices, but not necessarily the commissioner races or other policymaking offices. In sum, the social and political culture of Pennsylvania is still overwhelmingly draped in gender stereotypes. Positions with more executive or primary decision-making powers were identified as male positions and the administrative offices were identified as women's work. One local office that was deemed to be better for male candidates was that of township supervisor, but that one needed a bit more explanation, which A.C. Stickel, Republican Chair of Blair County, provides:

Township supervisors, that used to be really known more as a county road supervisor, or township road supervisor. I know that sounds very 
sexist that a woman can't drive a dump-truck, but that used to be the way it was, not so much anymore as the townships have grown and become larger municipal governments. (Stickel 2012)

Mr. Stickel and a few other leaders were quick to explain the evolution of the township supervisor position and why it has roots in a gendered division of labor. Per Mr. Stickel's own explanation, men may make better candidates for this position because historically it is a position that required manual labor, which women were/are believed unable to do successfully. It is also possible that women are less likely to seek such positions because they know that the work is gendered and therefore they would not taken seriously as a contender for the office. I argue that it is beliefs about the nature of political offices, like township supervisor, row offices, and others, that inform the recruitment efforts. All of these ideas are built on gender stereotypes, which are deeply rooted in the political and cultural psyche of Pennsylvanians.

In sum, the culture of the county party is one that is rather conservative and relies on gender stereotypes to largely inform who should be active in politics as well as how they should be involved. The expectation seems to be that women and men follow gender stereotypes and are involved in politics based on gender roles. Women may be able to be accepted as leaders as long as their domains are contained within "women's work" like administrative row offices and men take on positions like commissioner and district attorney.

\section{Discussion}

Many scholars have identified the political party as an important variable in understanding the dearth of women in elective office (Cotter et al. 1984; Deber 1982; Hansen 1994; Mayhew 1986; Niven 2006; Sanbonmatsu 2006; Sorauf 1963). To begin to dissect this relationship, I have focused on the possible role that candidate recruitment has played in oversupplying male candidates to the Pennsylvania electorate. Thirty interviews were conducted representing at least 23 different counties. As one would suspect, each county has its own culture and storied past when it comes to politics, yet some patterns did begin to emerge as county leaders spoke of their recruitment process.

A majority of the interviewees spoke of an informal recruitment process that is typified by first speaking to individuals who are related to the political party structure and then moving outward to trusted organizations and clubs. Many leaders believe this to be a gender-neutral process in that they are "casting a wide net," by speaking to different individuals and organizations. We know that these circles are gendered (Crowder-Meyer 2013; Sanbonmatsu 
2006). Additionally, some of the organizations cited for assistance with recruitment have a traditionally male-dominated membership. If you are a county party leader recruiting from predominantly male spaces, you will get predominantly male candidates for public office.

Similarly, there were three leaders that spoke of recruitment in terms of using both an informal and formal process. Again, the party leaders articulated the formal process as inclusive and open to the community. However, men are more likely to believe themselves fit to serve, even when coming from the "feeder" professions to politics like business and the law (Lawless and Fox 2010). Party leaders who rely on formal advertisements to the community are unintentionally allowing a gendered process to take place.

Lastly, the third unique type of recruitment was described as a volunteer model. Party leaders again believed that they were leaving their door wide open to many different candidates by allowing community members to selfidentify as candidates. Similar to the formal recruitment model, the process is inherently gendered. The only difference is that the county party is taking a more passive role than those that employ the formal model. Taken together, all of these types of recruitment lead to an oversupply of male candidates for the Pennsylvania electorate. Only one county party chair spoke of intentionally including women as part of the pool of candidates. None of the other county party leaders spoke of engaging in an intentionally gender-inclusive effort for candidate recruitment.

As the interviews continued, it became clear that the paucity of women in Pennsylvania politics was not solely due to candidate recruitment processes, as those (in)actions do not occur in a vacuum. Rather, the gender imbalance in elective office is a culmination of a gendered candidate-recruitment process, a conservative culture, and a gendered gatekeeping process by the parties. By the way the leaders share their stories, women are less willing to volunteer to become candidates and they are recruited at a lower rate because they are not in the informal circles that are staged as the upcoming farm team. When women did run, party officials were quick to point out what positions they were most likely to run for-administrative row offices at the county level. Overall, according to the party leaders, the lack of women in Pennsylvania politics is rooted in traditional gender stereotypes as women are not found in the informal circles in which candidate recruitment occurs and/or because women do not want to volunteer for public leadership, as women are "too smart for politics."

Male and female county party leaders cited family work-life balance as well as women not being readily available as a reason for the gender gap. 
Another observation was confirmed with the interview data and that was the role that gender stereotypes played in matching potential candidates to public office. Very clear patterns emerged in the interview data: male candidates would be better at the more "masculine" offices that focused on law, order, and executive powers, whereas female candidates would be better at offices that focused on justice and legislative and administrative powers. So, when women can and do run for office, they should run for the feminine offices. This line of thinking stems directly from the traditional and conservative culture described by the party leaders.

Another narrative that unveiled itself in the interviews was also one of unawareness of the gendered nature of their gatekeeping role. The leaders often believed that they were sage advice givers, informing potential candidates of conflicts and time commitments. Yet, examples provided were ones that deterred women from running for office. Other examples of gatekeeping were more non-descript and gave loose responses about how one evaluates leadership skills. Unfortunately, again, this can lead to a male selection bias (Niven 2006).

Yet, even with all of these variables at play to depress women's candidacies, there were increases of women's representation at both the state and federal levels. These increases coincide with an increase in the number of women's organizations working to increase descriptive representation. Examples of such independent political interventions on behalf of women include political action committees, organizations, and programs. ${ }^{10}$ Prior research claims independent organizations can play a positive role in increasing gender diversity among candidates (Sanbonmatsu 2006). Future research could inquire as to the effectiveness of these women's organizations and programs and how they may shape the balance of power in Pennsylvania's governing institutions. Are women's candidacies more successful with the support or education provided by one of these entities? How do these entities impact the traditional culture of the state? If change is to come to the state of Pennsylvania to provide for greater descriptive representation of its inhabitants, the change will most likely need to occur outside of the pre-existing party structure. In order to dramatically increase women's representation at the local, state, and federal levels in Pennsylvania, candidate recruitment processes must be intentionally diverse and inclusive. Given the evidence provided by this study, there is a potentially positive role for county party leaders to play in diversifying the pool of candidates, as Crowder-Meyer (2013) anticipates. However, education around the gendered impact of the party leaders' (non)actions would be necessary for change to occur. 


\section{NOTES}

1. Some recent studies investigating the roots of this underrepresentation have fallen into the following categories: lack of political ambition to run among potential female candidates (Bauer 2015, 2018; Fox and Lawless 2004; Kanthak and Woon 2015; Shafer 2008); lack of recruitment efforts by political parties and elites (Crowder-Meyer 2013; Niven 1998; Sanbonmatsu 2006); institutional constraints such as the incumbency advantage (Burrell 1994; Fox 1997); and reliance on gender stereotypes by voters (Bauer 2015, 2018; Ditonto and Mattes 2018; Huddy and Terkildsen 1993; Sanbonmatsu 2002).

2. Niven surveyed the county chairs of New Jersey, California, Ohio, and Tennessee.

3. The six states included in Sanbonmatsu's (2006) study are Ohio, Alabama, North Carolina, Massachusetts, Colorado, and Iowa.

4. The National Conference of State Legislatures identifies four states that have fulltime professional legislatures: California, Michigan, New York, and Pennsylvania. Of those four, Michigan has the highest proportion of women in its state legislature at a rate of $35.8 \%$. Pennsylvania holds the lowest percentage of the four states.

5. An example of Democrats being the minority party in Adams County is the fact that Barack Obama received only 35\% of the county vote in 2012.

6. At the time of this publication Dr. Mills is serving as Chair of the Democratic Party of the state of Pennsylvania.

7. At the time of the interview, one woman from Allegheny County was serving in the Pennsylvania State House of Representatives, Erin Molchany. However, she did not receive the party's endorsement in 2012 or 2014. She lost the party's 2012 endorsement to Martin Schmotzer, who was accused of stealing \$50,000 from Allegheny County when he worked there in 1997. She lost the 2014 endorsement to an incumbent Democratic colleague, State Rep. Harry Readshaw, after redistricting.

8. Confidential interviewee, 2012.

9. Confidential interviewee, 2012.

10. Anne Anstine Excellence in Public Service Series, Emerge Pennsylvania, Women for the Future Pennsylvania, Ready to Run Campaign Training for Women, and RepresentPA.

\section{REFERENCES}

Baer, Denise. 2013. "Welcome to the Party? Leadership, Ambition, and Support Among Elites." In Women \& Executive Office: Pathways and Performance, ed. Melody Rose. Boulder, CO: Lynne Rienner, 181-208.

Bauer, Nichole M. 2015. "Emotional, Sensitive, and Unfit for Office? Gender Stereotype Activation and Support Female Candidates." Political Psychology 36 (December): 691-708.

—. 2018. "Untangling the Relationship Between Partisanship, Gender, Stereotypes, and Support for Female Candidates." Journal for Women, Politics \& Policy 39 (1): 1-25. Belsey, Donald. 2012. Telephone Interview by Dana Brown. November 19.

Benner, Bill. 2012. Telephone Interview by Dana Brown. November 19.

Brown, Dana. 2015. “Parties Matter: The Impact of Pennsylvania's Parties on Women's Local Officeholding.” PhD diss., Rutgers University.

Burrell, Barbara C. 1993. "Party Decline, Party Transformation, and Gender Politics: The USA." In Gender and Party Politics, eds. Joni Lovenduski and Pippa Norris. London: Sage, 291-308. 
1994. A Woman's Place Is in the House: Campaigning for Congress in the Feminist Era. Ann Arbor: University of Michigan Press.

Carpenter, Megan. 2013. Telephone Interview by Dana Brown. May 13.

Cotter, Cornelius P., James L. Gibson, John F. Bibby, and Robert J. Huckshorn. 1984. Party Organizations in American Politics. New York: Praeger.

Crowder-Meyer, Melody. 2010. "Local Parties, Local Candidates, and Women's Representation: How County Parties Affect Who Runs For and Wins Political Office." PhD diss., Princeton University.

— 2013. "Gendered Recruitment without Trying: How Local Party Recruiters Affect Women's Representation.” Politics \& Gender 9 (December): 390-413.

Deber, Raisa. 1982. “The Fault, Dear Brutus': Women as Congressional Candidates in Pennsylvania." The Journal of Politics 44 (May): 463-479.

Decker, Christopher. 2012. Telephone Interview by Dana Brown. October 31.

Ditonto, Tessa. 2017. "A High Bar or a Double Standard? Gender, Competence, and Information in Political Campaigns." Political Behavior 39 (June): 301-325.

Ditonto, Tessa, and Kyle Mattes. 2018. "Differences in Appearance-Based Trait Inferences for Male and Female Political Candidates." Journal of Women, Politics \& Policy 39 (4): 430-450.

Dolan, Julie, Melissa Deckman, and Michele L. Swers. 2007. Women and Politics: Paths to Power and Political Influence. Upper Saddle River, NJ: Prentice Hall.

Fontana, Wayne. 2012. Telephone Interview by Dana Brown. September 19.

Fox, Richard L. 1997. Gender Dynamics in Congressional Elections. Thousand Oaks, CA: Sage.

Fox, Richard L., and Jennifer Lawless. 2004. "Entering the Arena? Gender and the Decision to Run for Office." American Journal of Political Science 48 (April): 264-280.

Glick, Peter, and Susan T. Fiske. 2001. "An Ambivalent Alliance: Hostile and Benevolent Sexism as Complimentary Justifications of Gender Inequality." American Psychologist 56 (February): 109-118.

Hansen, Susan B. 1994. "Lynn Yeakel Versus Arlen Specter in Pennsylvania: Why She Lost." In The Year of the Woman, eds. Elizabeth Adell Cook, Sue Thomas, and Clyde Wilcox. Boulder, CO: Westview, 85-108.

Huddy, Leonie, and Nayda Terkildsen. 1993. "Gender Stereotypes and the Perception of Male and Female Candidates." American Journal of Political Science 37 (February): 119-147.

Kanthak, Kristin, and Jonathan Woon. 2015. "Women Don't Run? Election Aversion and Candidate Entry.” American Journal of Political Science 59 (July): 595-612.

Lawless, Jennifer L., and Richard L. Fox. 2005. It Takes A Candidate: Why Women Don't Run for Office. New York: Cambridge University Press.

- 2010. It Still Takes A Candidate: Why Women Don't Run for Office. New York: Cambridge University Press.

Levin, Marilyn. 2012. Telephone Interview by Dana Brown. October 25.

Lund, Roger. 2012. Telephone Interview by Dana Brown. September 24.

Mayhew, David R. 1986. Placing Parties in American Politics: Organization, Electoral Settings, and Government Activity in the Twentieth Century. Princeton, NJ: Princeton University Press.

Miller, William. 2012. Telephone Interview by Dana Brown. September 25.

Mills, Nancy. 2012. Telephone Interview by Dana Brown. November 30.

NCSL (National Conference of State Legislatures). 2017. "Full and Part-Time Legislatures.” http://www.ncsl.org/legislatures-elections/legislatures/full-and-part-time -legislatures.aspx. Accessed December 2, 2019. 
Niven, David. 1998. The Missing Majority: The Recruitment of Women as State Legislative Candidates. Westport, CT: Praeger.

.2006. "Throwing Your Hat Out of the Ring: Negative Recruitment and the Gender Imbalance in State Legislative Candidacy." Politics \& Gender 2 (December): 473-489.

Palmer, Barbara, and Dennis Simon. 2012. Women \& Congressional Elections: A Century of Change. Boulder, CO: Lynne Rienner.

Politico. 2014. “2012 Pennsylvania Presidential Election Results.” http://www.politico .com/2012-election/results/president/pennsylvania/. Accessed May 21, 2014.

Sanbonmatsu, Kira. 2002. "Gender Stereotypes and Vote Choice." American Journal of Political Science 46 (January): 20-34.

- 2006. Where Women Run: Gender and Party in the American States. Ann Arbor: University of Michigan Press.

Sanbonmatsu, Kira, Susan J. Carroll, and Debbie Walsh. 2009. Poised to Run: Women's Pathways to the State Legislature. Center for American Women and Politics, Eagleton Institute of Politics, Rutgers University. Available at http://www.cawp.rutgers .edu/research/reports/PoisedtoRun.pdf.

Shafer, Karen. 2008. "Who Wants to Run for Office? Political Ambition Among Women Activists." PhD diss., Arizona State University.

Shaffer, Ruth Ann. 2012. Telephone Interview by Dana Brown. October 11.

Smith, Jeff. 2012. Telephone Interview by Dana Brown. September 14.

Sorauf, Frank J. 1963. Party and Representation: Legislative Politics in Pennsylvania. New York: Atheron.

Soss, Joe. 2005. “Talking Our Way to Meaningful Explanations: A Practice-Centered View of Interviewing for Interpretive Research." In Interpretation and Method: Empirical Research Methods and the Interpretive Turn, eds. Dvora Yanow and Peregrine Schwartz-Shea. Armonk, NY: M.E. Sharpe, 127-149.

Stickel, A.C. 2012. Telephone Interview by Dana Brown. October 30.

Trounstine, Jessica. 2008. Political Monopolies in American Cities: The Rise and Fall of Bosses and Reformers. Chicago: University of Chicago Press.

Williams, Marcia. 2012. Telephone Interview by Dana Brown. September 25.

Dana M. Brown is the executive director of the Pennsylvania Center for Women and Politics and assistant professor of political science at Chatham University. She has presented research on women in politics, political psychology, political media, and political participation by women of color. She is also active in the community. She currently serves in the following capacities: Governor Wolf's Pennsylvania Commission for Women, PLEN's (Public Leadership Education Network) Board of Directors, Adagio Health's Advisory Council, a delegate to the Vision 2020 program at Drexel University, and the Pennsylvania Advisory Committee to the U.S. Global Leadership Coalition. 